\title{
The economic and financial impact of the first phase of the COVID-19 pandemic on the sports market
}

Authors' Contribution:

A Study Design

B Data Collection

C Statistical Analysis

D Data Interpretation

E Manuscript Preparation

F Literature Search

G Funds Collection

\author{
Joanna Jedel ABDE, Marcin Burchard ABDEF \\ Gdansk University of Physical Education and Sport in Gdansk, Poland
}

abstract

Background: For the last several months, the world has been dominated by the coronavirus pandemic that effectively stopped the activity of entities in all fields of social life: finance, economy, culture and, broadly defined sport. The dynamic nature of changes and adaptation to a new reality were related to new restrictions and limitations on the functioning of society that were imposed by local governments.

Material and methods:

The authors analysed available reports that described the general results of the sports market as well as reports and financial statements for the period of the COVID-10 pandemic published by public jointstock companies operating in different segments of the sports industry.

Results: As a consequence of social isolation, society does not regularly practice physical activity, which may lead to deterioration in mental state and increase anxiety and stress. Because of the pandemic, millions of jobs around the world are at risk. Technology, including access to the Internet and on-line content customised to individual users' needs, is an excellent solution to alleviate the effects of social isolation. E-sports have become very popular in the mass media, not only in the digital world, going beyond internet streaming services, social media and websites for strategic game lovers. Since traditional league games have been suspended or cancelled, the coverage of e-sports events has appeared on television.

Conclusions: Today, it can be said that the COVID-19 pandemic has exerted and continues to exert a significant negative influence on the sports market, taking into consideration both economic and social aspects. It does not concern only people who work in professional sports but also those who work in related sectors such as retail or sport services that manage leagues and events. The COVID-19 pandemic has proved to be fraught with economic consequences.

Key words: sport management, COVID-19, business model, sport finance, sport organisation.

\section{article details}

Article statistics: Word count: 5,383; Tables: 5; Figures: 2; References: 14

Received: June 2021; Accepted: October 2021; Published: October 2021

Full-text PDF: http://www.balticsportscience.com

Copyright @) Gdansk University of Physical Education and Sport, Poland

Indexation: Celdes, Clarivate Analytics Emerging Sources Citation Index (ESCI), CNKI Scholar (China National Knowledge Infrastructure), CNPIEC, DOAJ, EBSCO - Central \& Eastern European Academic Source, EBSCO - SPORTDiscus, EBSCO Discovery Service, Google Scholar, Index Copernicus, J-Gate, Naviga (Softweco, Primo Central (ExLibris), ProQuest - Family Health, ProQuest - Health \& Medical Complete, ProQuest - Illustrata: Health Sciences, ProQuest Nursing \& Allied Health Source, Summon (Serials Solutions/ProQuest, TDOne (TDNet), Ulrich's Periodicals Directory/ ulrichsweb, WorldCat (OCLC)

Funding: This research received no specific grant from any funding agency in the public, commercial, or not-for-profit sectors.

Conflict of interests: Authors have declared that no competing interest exists.

Corresponding author: Marcin Burchard, Gdansk University of Physical Education and Sport, 80-336 Gdansk,Gorskiego 1, Poland; e-mail: marcin.burchard@awf.gda.pl

Open Access License: This is an open access article distributed under the terms of the Creative Commons Attribution-Non-Commercial-NoDerivatives 4.0 International (https://creativecommons.org/licenses/by-nc-nd/4.0/), which permits use, distribution, and reproduction in any medium, provided the original work is properly cited, the use is non-commercial and is otherwise in compliance with the license. 


\section{INTRODUCTION}

For the last several months, the world has been dominated by the coronavirus pandemic that effectively stopped the activity of entities in all fields of social life: finance, economy, culture and, broadly defined, sport. The dynamic nature of changes and adaptation to a new reality were related to new restrictions and limitations on the functioning of society that were imposed by local governments. Information about the postponement or cancellation of mass sports events in all disciplines, including marathons, football, athletics, basketball, handball, hockey, rugby, cricket, sailing, skiing, weightlifting, to name a few, created confusion in the sports world. For the first time in the history of the modern Olympics, the Olympic Games and the Paralympic Games were postponed and took place in 2021. Today, it can be said that the COVID-19 pandemic has exerted and continues to exert a significant negative influence on the sports market, taking into consideration both economic and social aspects. The suspension of international sports events and national and regional matches means that organisers, sportspeople and stakeholders will not earn income [1]. The lack of receipts and budget cuts made by television stations and sponsors has caused many sports clubs to not fulfil their obligations, especially towards the players.

According to the definition, the sports market consists of three main segments:

1. the segment of active amateur and professional sports performance comprises:

a. private enterprises and clubs organised as joint-stock companies and associations that offer different forms of organised sports by amateur and professional performers who usually focus on league games or competitive sports tournaments and games;

b. associations, unions and sports organisations that organise games, formulate and codify rules and regulations, arrange dates and establish licensing obligations;

c. different types of non-profit organisations whose activity is based on the commercialisation and professionalisation of action, focusing on processes and statutory activities that do not serve to make profits and distribute them to their members (shareholders) at fiscal year-end. More often than not, these organisations are beneficiaries of grant programmes, local government subventions and designated subsidies to realise municipality own tasks. This group includes school sports clubs and secular and religious sports associations that promote sport as a way to educate and shape appropriate attitudes;

d. fitness clubs and physical recreation centres organised as commercial companies and partnerships and sole proprietorships that organise physical activities, recreation and sports events in the form of outdoor events, mass events, amateur tournaments;

2. the segment of producers of goods and services that increase comfort and safety, improve organisation and optimise processes:

a. sports clothing and sportswear that are necessary to perform sports and increase the quality of sports performance;

b. equipment and accessories that are required to realise the rules of tournaments and sports performance;

c. services related to teaching the rules of sports performance, training and a widelyunderstood concept of developing sports skills;

d. services related to sports medicine, rehabilitation and development of health-oriented attitudes;

e. services related to the maintenance of sports facilities that are essential to sports performance and organisation of tournaments;

f. services related to the organisation and management of tournaments, formulation of rules and regulations and auditing and performing licensing processes in professional sports;

3. the segment of promotion through sports, sports sponsoring and marketing:

a. producers of gadgets and promotional merchandising products.

b. organisers of sport-related services, events and promotional events that are supported by a club's or sportsperson's brand. 
c. the media, including sports media and the media supported by club brands and sports organisations (FIFA, UEFA, IOC).

d. the sports sponsorship market that makes use of sports brands' potential to increase the conversion of sponsor's and sponsee's brand.

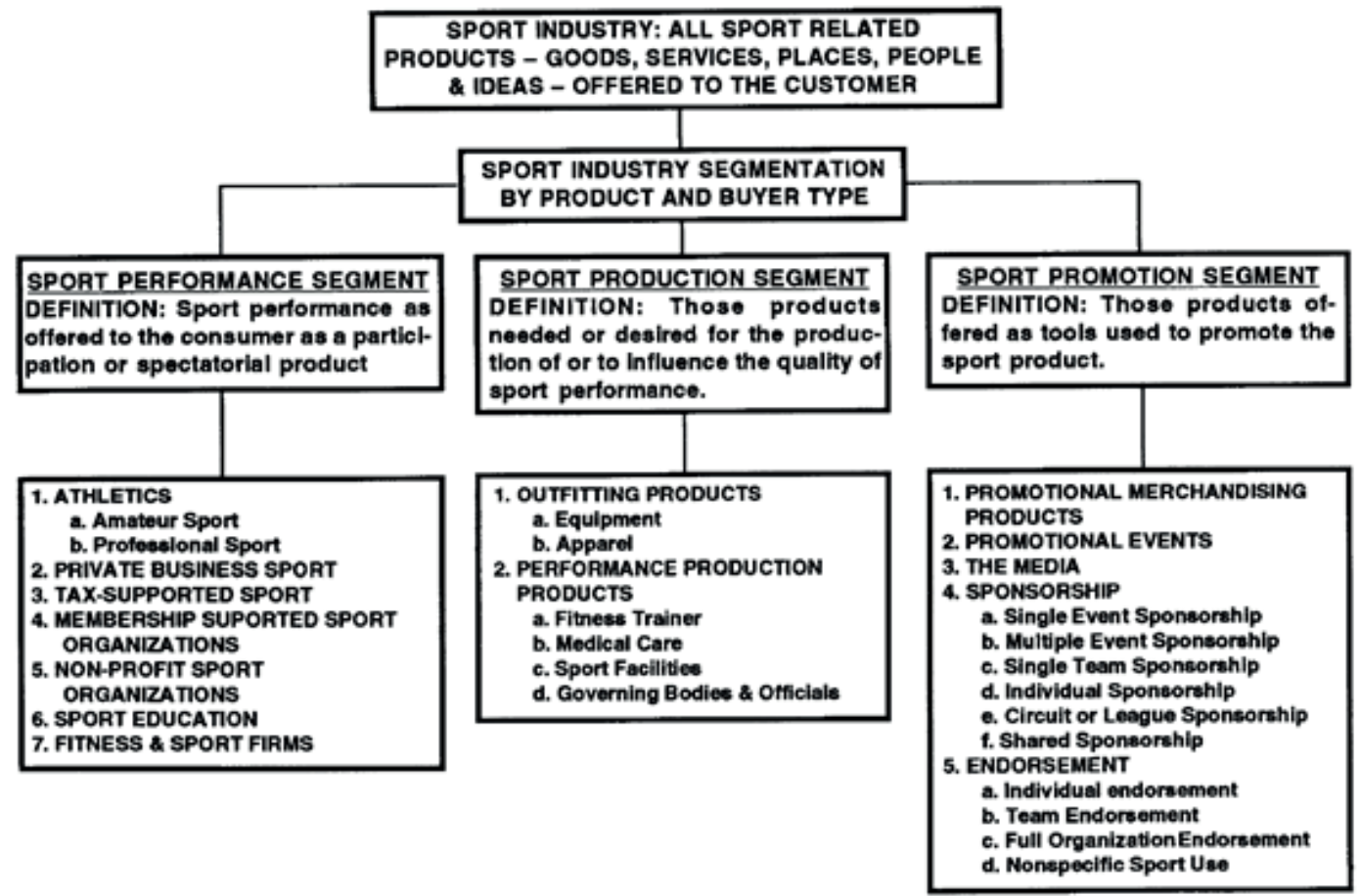

Fig. 1. Sport Industry Segment Model. B.G. Pitts, L.W. Fielding, L.K. Miller [1]

Because of the pandemic, millions of jobs around the world are at risk. It does not concern only people who are engaged in professional sports but also those who work in the related sectors, for example, retail or sports services connected to leagues and events that include travelling, tourism, infrastructure, transport, gastronomy and broadcasting. Professional sportspeople also remain under intense pressure; they have to modify their training programme, keep fit, risk losing income and breaching sponsorship agreements because they cannot comply with their obligations.

\section{MATERIAL AND METHODS}

The authors analysed available reports that described the general results of the sports market as well as reports and financial statements for the period of the COVID-10 pandemic published by public joint-stock companies operating in different segments of the sports industry [reports by Two Two Circles, Deloitte and Nielsen Audience Measurement; a financial statement by Manchester United Football Club; a financial statement for investors of Adidas AG; a quarterly report by Electronic Arts]. Due to the lack of detailed literature on the subject of the current phenomena related to COVID-19, the authors focused on monitoring the newest source information, aggregating and generalising data to isolate market trends.

\section{DISCUSSION}

The impact of the COVID-19 pandemic (severe acute respiratory syndrome coronavirus 2, i.e. SARS-CoV-2) has already been recognized in the scientific literature. With the advent 
of the virus and the emergence of organizational and economic constraints, the impact of the pandemic on the sports market began to be analysed. In this context, A. Wiśniewski, following Z. Waśkowski, defines the sports market as a structure consisting of four basic pillars.

Table 1. The subjective structure of the sport industry [2]

\begin{tabular}{llll}
\hline People & Sport institutions & Commercial enterprises & Media \\
\hline $\begin{array}{l}\text { people from the im- } \\
\text { mediate surroundings of } \\
\text { athletes }\end{array}$ & $\begin{array}{l}\text { organizers and enti-tles } \\
\text { managing profes-sional } \\
\text { sport }\end{array}$ & $\begin{array}{l}\text { licensee, specialised } \\
\text { consulting companies }\end{array}$ & modern digital media \\
$\begin{array}{l}\text { managers, agents, } \\
\text { advisors }\end{array}$ & $\begin{array}{l}\text { sport international } \\
\text { organizations, inter- } \\
\text { national Olympic } \\
\text { committee }\end{array}$ & sponsors & sports media \\
& $\begin{array}{l}\text { national sports or- } \\
\text { ganizations }\end{array}$ & $\begin{array}{l}\text { suppliers of sports } \\
\text { equipment }\end{array}$ & media broadcasting sports \\
sthletes & sports clubs & & spectacles \\
\hline
\end{tabular}

The so-far shaped sports market is affected by the impact of the pandemic in the form of restrictions in some areas and certain symptoms of development in other areas of the sports market. Undoubtedly, the beginning of the pandemic and the subsequent lockdowns of social and, above all, economic life introduced by individual governments resulted in significant restrictions in the development of the sports market. According to J. Grix et al., 'The rapid transmission of the virus, which has led thus far to the loss of over a million humans lives throughout the world, has meant that sport and sporting events have been cancelled, postponed or altered so that competitions can take place but without spectators (see also: Malcolm and Velija 2020, Parnell et al. 2020). When set alongside job losses, sickness and death, sport rightly appears trivial in comparison, a luxury or trivial pursuit, often - as with the arts - categorised under 'hobbies' or things to do once the serious business is over. While this is undoubtedly true, we argue that watching and participating in sport offers one of the most powerful cultural forces needed for many people to get through the difficult times of lockdown and limited social interaction brought about by the pandemic.' [3]

Such observations have become a permanent element of the authors' deliberations, who analyse the market on a daily basis, including the sports market. These observations are also confirmed by John Nauright et al.: 'Clubs and organizations lost billions as a result of pandemic cancellations. As Swanson and Smith explain in this issue, the decision to cancel the March Madness college basketball tournament in the USA cost universities \$375 million in lost revenues. [...] Much of this was attributed to rapid growth in sport-related tourism, quoting the UNWTO, they state that "international sports tourism as being one of the primary reasons for this global growth in tourism". COVID-19 stopped this growth in its tracks during 2020' [4]. The same authors note not only a significant limitation of the global sports market, but also a significant impact of SARS-CoV-2 on the areas that have so far contributed to the expansion of this market, constituted the main development trends and allowed manufacturers and service providers to expand the offer, collections and project portfolio for the implementation of new strategies and newly discovered target groups of customers: 'The COVID-19 crisis created an unprecedented disruption of sport around the globe. However, its impacts are not evenly dispersed. Experts and activists are raising the alarm - sport for girls and women, sport in low and middle-income countries and sport for people with disabilities will suffer disproportionately' [4].

While the feminization of sport, the development of sport for people with disabilities and recreational mass sport have significantly slowed down and limited, another trend in the 
sports market, i.e. digitization, has noticeably accelerated. YasinKaraca and Metin Can Kalayci noted the following: 'The epidemic accelerated the digitalization of the sports sector and the integration of technology with sports. Thanks to the integration of sports with technology, mobile phones that identify and recognize the individual, and applications that collect personal information, physical activities, training programs, nutrition and motivation programs specific to the individual have started to help the individual to organize his daily life. Now, thanks to technological tools, trainers can make individuals do sports activities in front of cameras without any time and place limitations. Thus, technology makes it possible for individuals to follow their coach from home' [5]. J. Nauright et al. noted similar observations of the sports market and changes in the way it functions in the field of digitization and changes in the attitudes and expectations of customers in this market. The pandemic highlighted and accelerated the development of a new branch of the market, i.e. e-sports: 'E-Sports and its related events are rapidly expanding industry sectors. With one of the best operations and management systems in the world, E-Sports in South Korea is now a billion dollar a year industry. In particular, the E-Sports market is getting bigger and better as a result of the COVID-19 pandemic. [...] With the best infrastructure for e-sports, including 5G internet and world-leading electronic companies (e.g., Samsung and LG), e-sports in Korea is becoming as a large component of daily leisure activities. [...] While mass e-sports events are suffering, virtual events are much easier to operate than for other "sport" forms' [4].

In most of the published works and articles, the authors emphasize not only economic, but also social aspects of the impact of the coronavirus pandemic on the sports and recreation market. For example, J. Grix et al., discussing the British market, noted and generalized that: 'For UK citizens - as for citizens of most high infection countries - such lockdown measures have included the closure of indoor public spaces, such as restaurants, bars, gyms, leisure centres and 'non-essential shops', the cancelling of events, such as weddings and festivals, and the national order that people should only leave their homes for 'limited reasons', such as for 'essential food shopping, exercise once per day, medical need and travelling for work when absolutely necessary' (The Independent, 23 September, 2020). While lockdowns are effective at lowering both Covid-19 cases and deaths, they are not long-term solutions, with cases soon rising once restrictive measures are lifted. However, and despite their significant impact on national and global economies, lockdowns are nonetheless necessary to controlling the spread of the virus until such a time that a Covid-19 vaccine becomes widely available, which, at the time of writing, looks unlikely to be any time before Spring 2021 (see: The Guardian, 19 October, 2020)' [3].

\section{RESEARCH GOAL}

The analysis of data provided by European professional football leagues, a professional football club, a global producer of sportswear and a media company that publishes information that is essential for clubs to generate income for sponsorship and sale of broadcast rights allowed the authors to find an answer to the question described in the introduction regarding the scale and impact of the COVID-19 crisis on services and production on the sports market. The article is also an introduction to the analysis of sports clubs' and the sports market's business model volatility in the context of the crisis provoked by the COVID-19 virus.

\section{RESULTS}

The global sports market is worth approximately USD 756 billion annually [2]. According to a new international forecast, the sports sponsorship market's revenues will decrease by USD 17.2 billion (GBP 14.1 billion) due to the coronavirus pandemic. A fall of approximately 
$37 \%$ is expected (year-on-year). The decline in revenue will be visible in the case of financial services companies, experiencing a decrease of $45 \%$ to USD 6.9 billion. A sports marketing company Two Two Circles stated that this sector contributed USD 12.6 billion to sports sponsorship last year, which was more than a quarter of the total amount spent [6]. Due to the economic crisis provoked by the COVID-19 pandemic, most new sponsorship agreements were suspended, and many existing agreements were terminated because companies wanted to cut costs and save funds in uncertain times.

Major sports organisations showed their solidarity with efforts to reduce the spread of the virus. For example, FIFA collaborated with the World Health Organisation (WHO) and launched the "Pass the message to kick out coronavirus" campaign [7] led by famous football players in 13 languages, developing people's awareness of five key steps to stop the spread of the disease. It focused on handwashing, coughing etiquette, not touching the face, social distancing and staying at home if feeling unwell. Simultaneously, other international sports organisations for development and peace decided to support each other and work together, organising, for example, periodic discussions of their on-line community to share their problems and challenges that would have to be faced in the nearest future.

It should also be added that because of the COVID-19 virus, educational institutions around the world were closed. Such a situation influenced the sector of sports education that included a wide circle of interested parties such as national ministries and local authorities, public and private educational institutions, sports organisations and sportspeople, non-profit organisations and business groups, teachers, lecturers and coaches, parents and, above all, mainly young students. The global pandemic led to the closure of gymnasiums, stadiums, pools, dance and fitness studios, physical therapy centres, parks and playgrounds. As a consequence of social isolation, society did not regularly practise physical activity, which might lead to deterioration in mental state and increase anxiety and stress. Technology, including access to the Internet and on-line content customised to individual users' needs, such as free training and courses in social media, meditation, yoga, or dance classes in which the whole family could participate, was an excellent solution to alleviate the effects of social isolation.

Undoubtedly, professional sport is an essential branch of industry. Every year, the European football market, which in 2019 was estimated to be more than EUR 28 billion, reported a record growth. A favourable economic situation of the football business was influenced, above all, by the results of the "big five" European football leagues (Bundesliga, La Liga, Ligue 1, the Premier League and Serie A), especially the Premier League that strengthened its leading position in terms of revenue. The second position was occupied by the Bundesliga that Spanish La Liga followed. These were the main conclusions from the 28th edition of the Annual Review of Football Finance 2019 prepared by advisory company Deloitte [8]. Currently, it is impossible to predict the 2020 estimates. It can be observed, however, that the football industry sustained massive losses due to the pandemic. On 19 February 2020, at the legendary San Siro stadium in Milan, more than 40,000 supporters watched the FC Atlanta-FC Valencia game in the first leg of the Champions League's round of 16. The match was said to contribute to the outbreak of the COVID-19 epidemic in Bergamo and Milan. Two days later, the first death from coronavirus was confirmed near Padua. On 4 March, 15 days after the match, Bergamo's epidemic curve began to rise very fast; it seemed apparent that the virus might have spread during the Champions League event. The date is almost historical for the football market. Most important European leagues put on hold their games, except for the Belarusian Premier League that decided to continue the season. Although the number of infections was growing, the matches were played with supporters in stadiums and the broadcast rights were bought by TV stations from 
Russia and Ukraine. As a result, the league became more popular, exposing the health of players, club staff and supporters to a risk. When European games were suspended, the question about the future of football arose. Initially, UEFA categorically demanded top divisions in every country to finish their seasons. It was dictated by a desire to determine the winners, relegated teams and the teams that would be qualified to the international games in the following season. With national leagues having finished their seasons, it would be possible to play matches in the UEFA Champions League and the UEFA Europa League in the 2019-20 season. Before all Champions League matches were suspended, four out of eight quarter-finals had been established. In the Europa League case, six matches of the $1 / 8$ finals had been organised, not including any rematch. It should be underlined that an unfinished season might have serious consequences. The clubs would not receive funds from sponsors and television for the services defined in agreements. Also, UEFA would be unable to pay the interested clubs, depleting their funds. Final decisions were to be made during a meeting of the UEFA Executive Committee organised in the second half of June.

In terms of national games, Prime Minister of the Netherlands Mark Rutte declared at the end of April that professional football matches would be banned until 1 September 2020. Several days later, the Royal Dutch Football Association decided that the Eredivisie campaigns would end due to the coronavirus crisis, with no champions and no teams relegated or promoted to the elite. This decision was met with criticism among several clubs, including first-league SC Cambuur-Leeuwarden that was the leader of the EersteDivisie, which intended to take legal action against the association. FC Utrecht occupied the sixth position. However, the club had a postponed match to play; in case of victory, it would advance to the sixth position that guaranteed participation in the Europa League's eliminations. The association's decision deprived the club of this opportunity. It remains unknown how the two top clubs with the same number of points, Ajax Amsterdam and AZ Alkmaar, would behave. Probably, they would play against each other for the championship. The French Football Federation also announced that the season ended. In effect, Paris Saint-Germain was crowned champions. The French authorities decided to select the best teams based on the points-per-game ratio. One of the teams that lost due to the cancelled season was Olympique Lyonnais; for the first time in twenty years, the club would not be qualified for European competition and would lose an opportunity to win the league cup. The Amiens officials were also dissatisfied with the French league's decision. The team was relegated, although being four points away from the lifeline of a play-off spot. The remaining most significant leagues in Europe postponed a decision on whether to cancel the season. The Bundesliga was the first of the top European leagues to approve official matches during the COVID-19 pandemic. The German Football League (DFL) with the German government resumed the season on 16 May 2020. Matches could be viewed only on television, and a plan to open stadiums for spectators was postponed. Nevertheless, players' comeback met with the joy of most football fans; it also played an important social role. In Germany, professional football is highly dependent on funds that come from selling broadcast rights. Without money from television stations, many clubs would probably not survive until the following season. Indeed, the football industry is currently huge, yet it only generates one product - a football match. If it is unable to provide such a product, the whole industry has a severe problem. The Austrian Football Bundesliga and the Czech First league also resumed the season. The Italian Serie A, the Spanish La Liga and the English Premier League planned to return to action soon. The revenue disparity between European leagues and national clubs is growing. This trend will intensify due to the COVID-19 pandemic because the biggest football clubs will keep the revenue predicted in the contractual clauses, whereas smaller clubs will be dependent on the revenues from sales on match days and one-season trade agreements. Deloitte's analysis predicted that the 2019-20 season's disruption caused by the pandemic would influence the decline in Premier League clubs' revenue by approximately EUR 1.1 billion in the 2019-20 budget year. 
After a three-month break, the Polish Ekstraklasa, First League and Second League were resumed. The lack of receipts and budget cuts made by television stations and sponsors caused many sports clubs to not fulfil their obligations, especially from sponsorship agreements, towards the players. In the short term, this meant pay cuts, including the top players, which was possible due to the Ekstraklasa supervisory board's decision that clubs were entitled to reduce their players' salaries by $50 \%$ to the sum not lower than PLN 10,000 gross; approximately 90\% of Ekstraklasa clubs would follow that decision. A significant impact of the coronavirus pandemic could be observed in the organisational structures of Polish football clubs. According to legia.net, about 40 people working in the marketing and media department of Legia Warsaw were dismissed. These included staff members who were responsible for advertising, public relations and media services. The football season's resumption did not influence thousands of people who worked in stadiums, club shops, snack bars, museums or box offices; they would remain unemployed.

The COVID-19 pandemic has revealed that the market reality, which is also based on the commercialisation of the sports market, does not abhor a vacuum. When the existing elements of the sports market were limited or blocked, which was experienced in the European market from February or March to May and June 2020 depending on a country, e-sports with all its elements usually associated with traditional sports appeared. Being a new branch of the sports market, it is not included in the described model. E-sports became very popular in the mass media, not only in the digital world, going beyond internet streaming services, social media and websites for strategic game lovers. Since traditional league games were suspended or cancelled, the coverage of e-sports events appeared on television. It covered both RPG and sports matches (FIFA, MBAK2), in which professional e-sports players and traditional football players participated, establishing mixed teams. Eurosport television sports network, a subsidiary of Discovery, broadcast a bicycle race in which riders from professional teams and pelotons and VIPs and celebrities took part. In the privacy of their homes, they were riding a cycle ergometer that had a particular application installed, taking part in an on-line race during which they were covering a virtual route. It turned out that victory depended not only on one's endurance but also on the stability and speed of Internet connection, a good bicycle, and well-prepared appliances connected to the network. The research on the rating points and share of specific television sports stations, performed by Nielsen Audience Measurement and published by Wirtualne Media on 16 June 2020 [9], showed that this strategy did not keep the audience shares in the media market. Therefore, it can be stated that e-sports belongs to the Internet, and the traditional media will only be an addition. The COVID-19 virus was a pretext for including e-sports into the programme; although hybrid forms of sports coverage appeared, they did not supplement the traditional offer.

In the case of Manchester United, the top representative of the Premier League, the financial results for the first three and the last quarter of the fiscal year (from April 2019 to June 2020) were presented in a quarterly report as of 21 March 2020 [10]. According to the statement, from January to March 2020, the club's total revenue decreased by almost $19 \%$ compared to the previous year's comparable period. Consequently, the management decreased operational expenses by $8.6 \%$ in relation to the same group of expenses covered in the previous year's comparable period. This means that the club sustained losses on operating activity of GBP 3,307 million. Moreover, the club was forced to cover the costs of external financing, resulting in a total loss of GBP 22,853 million for the period of the 2019-20 fiscal third quarter instead of over GBP 7 million in profit in the same period of 2019. It indicates that the EBIT for that year constituted $45 \%$ of gross profit reported in the previous fiscal year's comparable period. Therefore, considering the impact and limitations of the 2019-20 fiscal fourth quarter, it can be predicted that the profit of Manchester United PLC in the current fiscal year is expected to reach one-third of the 
last season's financial result. A similar decrease can be predicted in the case of one of the most critical indicators of a club's operating activities, which is financial liquidity, because the consolidated statement of cash flows included in the report presents that the value of cash flows declined by approximately $60 \%$ compared to the comparable period of the previous year.

Table 2. Summary of audience share of all sports networks available in the Polish television market (monitored by Nielsen Audience Measurement) in May 2020 [9]

\begin{tabular}{|c|c|c|c|}
\hline Wirtualnemedia.pl & \multicolumn{2}{|c|}{ All viewers aged 4+ } & \multirow{2}{*}{ Dynamics } \\
\hline \multirow{2}{*}{ TV station } & May 2019 & May 2020 & \\
\cline { 2 - 3 } & SHR \% & SHR \% & $\%$ \\
\hline TVP Sport & $0.995 \%$ & $0.297 \%$ & $-\mathbf{7 0 . 1 5 \%}$ \\
\hline Polsat Sport & $0.487 \%$ & $0.200 \%$ & $-\mathbf{5 8 . 9 3 \%}$ \\
\hline Eleven Sports 1 & $0.198 \%$ & $0.090 \%$ & $-\mathbf{5 4 . 5 5 \%}$ \\
\hline Canal+ Sport & $0.124 \%$ & $0.073 \%$ & $-\mathbf{4 1 . 1 3 \%}$ \\
\hline Extreme Sports & $0.065 \%$ & $0.073 \%$ & $\mathbf{1 2 . 3 1 \%}$ \\
\hline Polsat Sport News HD & $0.051 \%$ & $0.062 \%$ & $\mathbf{2 1 . 5 7 \%}$ \\
\hline nSport+ & $0.098 \%$ & $0.055 \%$ & $-\mathbf{4 3 . 8 8 \%}$ \\
\hline Polsat Sport Extra & $0.091 \%$ & $0.051 \%$ & $-\mathbf{4 3 . 9 6 \%}$ \\
\hline Eurosport 2 & $0.118 \%$ & $0.041 \%$ & $-\mathbf{6 5 . 2 5 \%}$ \\
\hline Eurosport 1 & $0.397 \%$ & $0.039 \%$ & $-\mathbf{9 0 . 1 8 \%}$ \\
\hline Polsat Sport Fight & $0.070 \%$ & $0.032 \%$ & $-\mathbf{5 4 . 2 9 \%}$ \\
\hline Canal+ Sport2 & $0.036 \%$ & $0.018 \%$ & $-\mathbf{5 0 . 0 0 \%}$ \\
\hline Eleven Sports 2 & $0.038 \%$ & $0.014 \%$ & $-\mathbf{6 3 . 1 6 \%}$ \\
\hline Canal+ Sport3 & - & $0.011 \%$ & - \\
\hline Fightklub & $0.007 \%$ & $0.007 \%$ & $\mathbf{0 . 0 0 \%}$ \\
\hline Canal+ Sport4 & - & $0.002 \%$ & - \\
\hline Motowizja & $0.010 \%$ & $0.002 \%$ & $-\mathbf{8 0 . 0 0 \%}$ \\
\hline
\end{tabular}

Table 3. Consolidated statement of profit or loss for the 2019-20 fiscal third quarter by Manchester United PLC. Earnings release published on 21.05.2020, p. 9.[10]

CONSOLIDATED STATEMENT OF PROFIT OR LOSS

(unaudited; in $£$ thousands, except per share and shares outstanding data)

\begin{tabular}{|c|c|c|c|c|}
\hline & \multicolumn{2}{|c|}{$\begin{array}{c}\text { Three months ended } \\
31 \text { March }\end{array}$} & \multicolumn{2}{|c|}{$\begin{array}{c}\text { Nine months ended } \\
31 \mathrm{March}\end{array}$} \\
\hline & 2020 & 2019 & 2020 & 2019 \\
\hline Revenue from contracts with customers & 123,711 & 152,068 & 427,537 & 495,706 \\
\hline Operating expenses & $(131,783)$ & $(144,181)$ & $(399,457)$ & $(448,030)$ \\
\hline Profit on disposal of intangible assets & 4,765 & 6,378 & 16,067 & 24,457 \\
\hline Operating (loss)/profit & $(3,307)$ & 14,265 & 44,147 & 72,133 \\
\hline Finance costs & $(25,758)$ & $(5,361)$ & $(19,701)$ & $(16,877)$ \\
\hline Finance income & 511 & 2,213 & 1.274 & 2.257 \\
\hline Net finance costs & $(25,247)$ & $(3,148)$ & $(18,427)$ & $(14,620)$ \\
\hline (Loss)/profit before income tax & $(28,554)$ & 11,117 & 25,720 & 57,513 \\
\hline Income tax credit(expense) & 5,701 & $(3,464)$ & $(12,438)$ & $(16,444)$ \\
\hline (Loss)/profit for the period & $(22,853)$ & 7,653 & 13,282 & 41,069 \\
\hline
\end{tabular}

Basic (loss)/earnings per share:

Basic (loss)/earnings per share (pence)

\begin{tabular}{rrrr} 
(13.89) & 4.65 & $\mathbf{8 . 0 7}$ & 24.96 \\
$\mathbf{1 6 4 , 5 4 4}$ & 164,526 & $\mathbf{1 6 4 , 5 6 3}$ & 164,526 \\
& & & \\
$(13.89)$ & 4.65 & 8.06 & 24.94 \\
& & & \\
164.544 & 164,664 & 164,746 & 164,664 \\
\hline
\end{tabular}

Weighted average number of ordinary shares used as the denominator in calculating basic

(loss) (eamings per share (thousands)

Diluted (loss)/earnings per share:

Diluted (loss)/earnings per share (pence)(n)

Weighted average number of ordinary shares and

potential ordinary shares used as the denominator in

calculating diluted (loss)/earnings per share

(thousands) (i)

$164.544 \quad 164,664 \quad 164,746$

(1) For the three months ended 31 March 2020 potential ordinary shares are anti-dilutive, as their inclusion in the diluted loss per share calculation would reduce the loss per share, and hence have been excluded. 
The results of Manchester United PLC are not as bad as the 2020 fiscal first quarter results of Adidas company, one of the leading producers of sports clothing and accessories in the world. In February and March 2020, the Chinese government decided to freeze the country's economic activity; in March, a similar action started in Europe. As a result, Adidas net sales in the 2020 fiscal first quarter decreased by $19 \%$ year-on-year. It was $-45 \%$ in the Asian market and $-58 \%$ in the Chinese mainland. Adidas operating margin, which is essential in retail, declined to $1.4 \%$. Along with the decrease in net income from continuing operations in the traditional sale channel, it provoked a decline in the company's profitability by $97 \%$. The increase of e-commerce by $35 \%$ improved the situation; however, on-line shopping was unable to compensate for the losses. Taking into consideration the future events, the spread of the COVID-19 pandemic in April and May in North America and Great Britain, which are the biggest sports markets, and European and Chinese markets' slow return to function, similar or worse results year-on-year should be expected in the second quarter of this year.

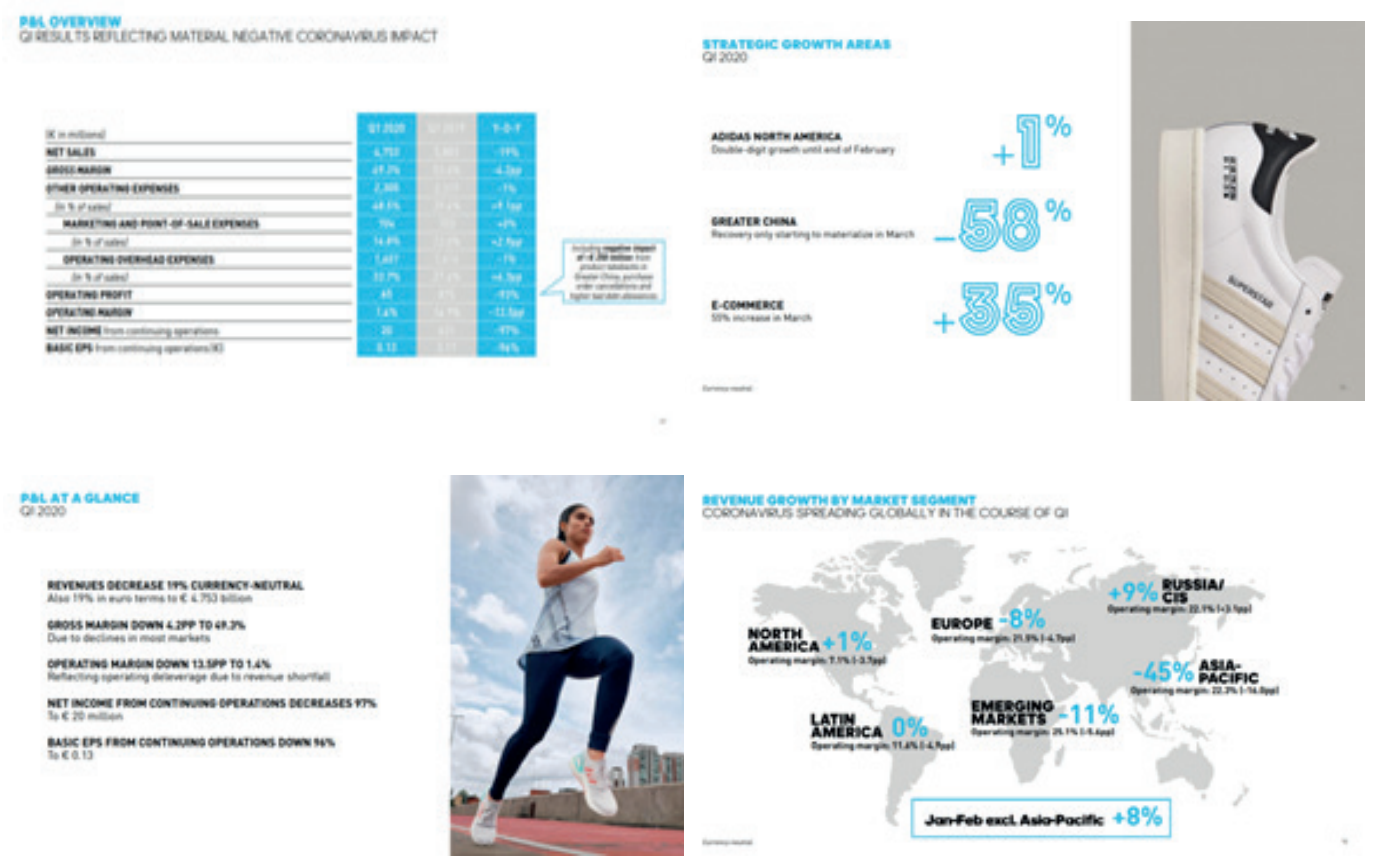

Fig. 2.Scan of crucial economic parameters from the financial statement for the 2020 fiscal first quarter results published by Adidas AG [11]

\begin{tabular}{|c|c|c|}
\hline \multirow{3}{*}{$\begin{array}{l}\text { (in S millions, except per share amounts) } \\
\text { Digital net revenue }\end{array}$} & \multicolumn{2}{|c|}{$\begin{array}{c}\text { Three Months Ended } \\
\text { March 31, }\end{array}$} \\
\hline & 2020 & 2019 \\
\hline & 1,219 & 1,065 \\
\hline Packaged goods and other net revenue & 168 & 173 \\
\hline Total net revenue & 1,387 & 1,238 \\
\hline Net income & 418 & 209 \\
\hline Diluted earnings per share & 1.43 & 0.69 \\
\hline Operating cash flow & 498 & 599 \\
\hline Value of shares repurchased & 291 & 301 \\
\hline Number of shares repurchased & 2.7 & 3.2 \\
\hline
\end{tabular}


Apart from Adidas's report, the trend of shifting sports market clients' interests and activities to on-line sales channel can be confirmed by a financial statement issued by one of the biggest sports video games companies, Electronic Arts Inc. [12]. In the first quarter of this year, the developer and producer of a famous series FIFA reported an increase in sales by approximately $15 \%$ and doubled the net income. This means that the clients' activity grew in the digitalised part of the sports market.

\section{CONCLUSIONS}

Will the world community adjust to the new lifestyle with the COVID-19 virus? It is beyond all doubt that the fight against the coronavirus is not over, and soon, another wave of infections will occur [13]. So far, many research papers and reports analysing the impact of the virus on the functioning of countries have appeared [14]. Based on these reports' conclusions, guidelines regarding sports functioning in the new reality should be prepared. It should be added that amateur clubs, which constitute the highest number of clubs in Poland, also had to face problems resulting from the pandemic; however, they are not discussed so broadly. The future of many teams that play in the lowest national leagues is unsure. Local authorities do not spend as much funds on clubs and associations as in 2019; private financing of sports has been mostly limited. In the short term, sportspeople, spectators, and shop assistants should be guaranteed the highest safety level for sports events to occur. In the medium term, in the face of a forecast of a global recession, it may also be necessary that state authorities designate funds for sports clubs and sportspeople on all levels, especially for non-commercial sports organisations that operate mainly in youth sports.

It is estimated that sports clubs will lose approximately $50 \%$ of revenue because of the lockdown and failure to satisfy their obligations related to revenues from sales on match days or media agreements that result from postponed games and matches without spectators. Since the season took almost a quarter longer (it ended after 30 June), the remaining part should be reported in the 2020-21 fiscal year. Therefore, the COVID-19 pandemic will negatively influence the financial results for this season, causing a significant decrease in revenue and operating losses in the European football market. Clubs have to face many financial challenges, including a decline in revenue, deferred revenues from commercial agreements and broadcasting, losses of match day revenue and other accompanying revenues and employment reduction in clubs' structures [8].

As a result of the COVID-19 pandemic, the existing business model of sports undertakings, based on the three groups of revenue, has changed. The imposed restrictions have successfully prevented clubs and sports events organisers from generating revenue from sales on match days. Moreover, it has become impossible to earn revenue with sponsors due to some formal and legal requirements. A sponsorship agreement is a service agreement. Thus, according to the Article 750 of the Polish Civil Code and, as a matter of principle, it should be treated as a contract of mandate. Its crucial element is not the result but a promise of a meticulous performance of an action. Since clubs and sports events organisers cannot perform any action, it is impossible to consider its meticulousness. Without performance, there are no formal and legal possibilities to make a payment because the agreed action has not been performed. As defined in the trading regulations, making payment for an unperformed action could be recognised as acting to the detriment of the sponsor. In common non-professional sports, funds can also be obtained from local authorities' financial support and grants and the national budget. Entrepreneurs, including professional sports clubs, can only apply for special funds granted under the anti-crisis shields and aid packages introduced by individual countries' government. Therefore, it is hard to expect that the COVID-19 pandemic has not negatively impacted the finances of professional football clubs. It is proved by quarterly reports published on-line and on the websites of financial institutions by clubs and enterprises that are stock exchange-listed companies. 
In the case of the traditional market that sells sports-related material goods, a dramatic decrease in the number of transactions, despite drastic retail price cuts, can be noticed. As a result, producers and distributors have experienced a decrease in net income and operating margin value. These two factors have a negative influence on the EBIT valuation. Besides, it can be noticed that clients' interest in on-line sales channel has increased. Presumably, it will speed up the digitalisation of the sales process and the digitalisation of the market, eliminating to greater extent distributors and agents. It may have a positive impact on producers' future operating margins. However, there is still not enough data to confirm that the traditional market's loss could be quickly recovered on the on-line market. A decline in margins on the product market and sports services will influence cash flows and statements prepared by sports enterprises. Imposed by state and local governments, social distancing will maintain the decrease in revenue from sales on match days and make supporters watch events through media coverage. The increase in the value of on-line commercial suggests that the Internet will be the leader of revenue growth in terms of coverage.

As a result of the pandemic, e-sports has made its presence heard on the market. However, it has not managed to substitute the traditional market, as can be observed in the results of television audience measurements for highly available thematic sports channels.

\section{REFERENCES}

[1] Pitts BG, Fielding LW, Miller LK. Industry Segmentation Theory and the Sport Industry: Developing a Sport Industry Segment Model. Sport Market Q. 1994;3(1):18.

[2] Wiśniewski A. Competitiveness of sports market enterprises: determinants, classification, challenges. Ekonomia i Prawo. Economics and Low. 2020;19(2).

[3] Grix J, Brannagan PM, Grimes H, Neville R. The impact of COVID-19 on sport. Int J Sport Policy Politics. 2020;13(1):1-12.

[4] Nauright J, Zipp S, Hoon Kim Y. The sports world in the era of COVID-19. Sport Society. 2020;23(1):1703-1706

[5] Karaca Y, Can Kalayci M. Sports activities in the COVID-19 pandemic process. Int J Life Sci Pharma Research. 2021; SP-14, Health and Sports Sciences.

[6] Warrington J. Coronavirus crises set to wipe 17 bn \$ off sports sponsorship market. City A.M.; 18.05.2020. https:// www.cityam.com/coronavirus-crisis-set-to-wipe-17bn-off-sports-sponsorship-market/ [accessed on 18.05.2020].

[7] Garwood P. Pass the message: Five steps to kicking out coronavirus. WHO, FIFA launch join campaign to equip football community to takle COVID-19. WHO media news release; 23.03.2020 https://www.who.int/campaigns/connectingthe-world-to-combat-coronavirus/pass-the-message-to-kick-out-corona [accessed on 06.06.2020].

[8] Giorgio P. Sport industry outlook. Breaking down the latest US Sport market for 2021 and beyond. Deloitte; 2021. https://www2.deloitte.com/us/en/pages/technology-media-and-telecommunications/articles/sports-business-trendsdisruption.html [accessed on 05.06.2020].

[9] Kurdupski M. Tylko 1,07 proc. udziału wszystkich kanałów sportowych w maju, spadek o 62 proc. [Only 1.07 percent. share of all sports channels in May, a decrease of 62 percent.].Wirtualna Polska; 16.06.2020. https://www. wirtualnemedia.pl/artykul/ogladalnosc-kanalow-sportowych-maj-2020-tvp-sport-lider [accessed on 02.08.2020]

[10] Manchester United PLC Report First Quarter Fiscal 2020 Results and Provides COVID-19 Impact. Manchester United PLC, Corporate Release; 05.2020 https://ir.manutd.com/ /media/Files/M/Manutd-IR/Governance\%20Document/ manchester-united-plc-3q20-earnings-release.pdf [accessed on 04.07.2020].

[11] Adidas Group Annual Report 2020, Investors Overview. Adidas AG Investors Relations, Herzogenaurach, Germany; 04.2020. https://www.adidas-group.com/en/investors/overview/ [accessed on 23.04.2020].

[12] Electronic Arts Reports Q4 and Full Year Fiscal Year 20 Financial Results. Electronic Arts Inc; 05.05.2020. https:// ir.ea.com/press-releases/press-release-details/2020/Electronic-Arts-Reports-Q4-and-Full-Year-FY20-Financial-Results/ default.aspx [accessed on 05.07.2020].

[13] McDonell S. Coronavirus: Fear of second wave in Beijing aftermarket outbreak. BBC News; 13.06.2020. https://www. bbc.com/news/world-asia-china-53034924 [accessed on 13.06.2020].

[14] Coronavirus: Impact on the pro sports industry worldwide. Report; 2020. https://www.statista.com/study/71572/thesports-industry-impact-of-the-covid-19-pandemic-2020/ [accessed on 17.06.2020]. 


\section{APPENDIX}

Table 5. Consolidated statement of cash flows for the 2019-20 fiscal third quarter by Manchester United PLC [10]

CONSOLIDATED STATEMENT OF CASH FLOWS

(unaudited; in $\mathrm{f}$ thousands)

\begin{tabular}{|c|c|c|c|c|}
\hline & \multicolumn{2}{|c|}{$\begin{array}{l}\text { Three months ended } \\
\text { 31 March }\end{array}$} & \multicolumn{2}{|c|}{$\begin{array}{l}\text { Nine months ended } \\
31 \text { March }\end{array}$} \\
\hline & 2020 & 2019 & 2020 & 2019 \\
\hline \multicolumn{5}{|l|}{ Cash flows from operating activities } \\
\hline $\begin{array}{l}\text { Cash generated from operations (see } \\
\text { supplemental note } 4 \text { ) }\end{array}$ & 34,333 & 29,803 & 15,894 & 112,140 \\
\hline Interest paid & $(7,944)$ & $(7,679)$ & $(17,895)$ & $(17,186)$ \\
\hline Debt finance costs paid & - & - & (555) & - \\
\hline Interest received & 115 & 697 & 1,165 & 2,052 \\
\hline Tax paid & (200) & (578) & $(1,897)$ & $(2,388)$ \\
\hline $\begin{array}{l}\text { Net cash inflow/(outflow) from operating } \\
\text { activities }\end{array}$ & 26,304 & 22,243 & $(3,288)$ & 94,618 \\
\hline \multicolumn{5}{|l|}{ Cash flows from investing activities } \\
\hline Payments for property, plant and equipment & $(4,662)$ & $(1,559)$ & $(17,692)$ & $(8,877)$ \\
\hline Payments for intangible assets & $(24,419)$ & $(14,809)$ & $(211,730)$ & $(159,865)$ \\
\hline Proceeds from sale of intangible assets & 3,225 & 12,709 & 25,234 & 37,892 \\
\hline Net cash outflow from investing activities & $(25,856)$ & $(3,659)$ & $(204,188)$ & $(130,850)$ \\
\hline \multicolumn{5}{|l|}{ Cash flows from financing activities } \\
\hline Acquisition of treasury shares & $(3,372)$ & $\cdot$ & $(3,372)$ & $\cdot$ \\
\hline Repayment of borrowings & - & $\cdot$ & $\cdot$ & $(3,750)$ \\
\hline Principal elements of lease payments(1) & (399) & $\cdot$ & $(1,160)$ & - \\
\hline Dividends paid & $(11,323)$ & $(11,610)$ & $(11,323)$ & $(11,610)$ \\
\hline Net cash outflow from financing activities & $(15,094)$ & $(11,610)$ & $(15,855)$ & $(15,360)$ \\
\hline $\begin{array}{l}\text { Net (decrease)/increase in cash and cash } \\
\text { equivalents }\end{array}$ & $(14,646)$ & 6,974 & $(223,331)$ & $(51,592)$ \\
\hline Cash and cash equivalents at beginning of & 100,856 & 190,395 & 307,637 & 242,022 \\
\hline $\begin{array}{l}\text { Effects of exchange rate changes on cash and } \\
\text { cash equivalents }\end{array}$ & 4,041 & $(3,514)$ & 5,945 & 3,425 \\
\hline Cash and cash equivalents at end of period & 90,251 & 193,855 & 90,251 & 193,855 \\
\hline
\end{tabular}

(1) Relates to adoption of IFRS 16, "Leases" with effeet from 1 July 2019. See supplemental note 5 for further details. 